medRxiv preprint doi: https://doi.org/10.1101/2020.05.14.20101725; this version posted May 19, 2020. The copyright holder for this preprint

\title{
COVID-19 Epidemic Forecast in Different States of India using SIR Model
}

\author{
Mukesh Jakhar $^{1}$, P. K. Ahluwalia ${ }^{2}$ and Ashok Kumar ${ }^{*}$ \\ ${ }^{1}$ Departmentof Physics, School of Basic and applied Sciences, Central University of Punjab, \\ Bathinda, India 151001 \\ ${ }^{2}$ Department of Physics, Himachal Pradesh University, Shimla, India 171005
}

(May 14, 2020)

*Email: ashokphy@ cup.edu.in

\begin{abstract}
The epidemiological data up to $12^{\text {th }}$ May 2020 for India and its 24 states has been used to predict COVID-19 outbreak within classical SIR (Susceptible-Infected-Recovered) model. The basic reproduction number $\mathrm{R}_{0}$ of India is calculated to be 1.15 , whereas for various states it ranges from 1.03 in Uttarakhand to 7.92 in Bihar. The statistical parameters for most of the states indicates the high significance of the predicted results. It is estimated that the epidemic curve flattening in India will start from the first week of July and epidemic may end in the third week of October with final epidemic size $\sim 1,75,000$. The epidemic in Kerala is in final phase and is expected to end by first week of June. Among Indian states, Maharashtra is severely affected where the ending phase of epidemic may occur in the second week of September with epidemic size of $\sim 55,000$. The model indicates that the fast growth of infection in Punjab is from $27^{\text {th }}$ April 2020 to $2^{\text {nd }}$ June 2020 , thereafter, curve flattening will start and the epidemic is expected to finished by the first week of July with the estimated number of $~ 3300$ infected people. The epidemic size of COVID-19 outbreak in Delhi, West Bengal, Gujrat, Tamil Nadu and Odisha can reach as large as 24,000, 18,000, 16,000, 13,000 and 11,000, respectively, however, these estimations may be invalid if large fluctuation of data occurs in coming days.
\end{abstract}


medRxiv preprint doi: https://doi.org/10.1101/2020.05.14.20101725; this version posted May 19, 2020. The copyright holder for this preprint (which was not certified by peer review) is the author/funder, who has granted medRxiv a license to display the preprint in perpetuity. It is made available under a CC-BY-NC-ND 4.0 International license .

\section{Introduction}

COVID-19 (Coronavirus disease 2019) is a disease caused by a novel virus called SARSCoV-2 (severe acute respiratory syndrome coronavirus 2) which has spread over more than 200 countries infecting more than 40 lakh peoples worldwide (as on May 12,2020) [1]. The outbreak of this disease was announced by World Health Organization (WHO) after one month from the reporting of first case on Dec. 31, 2019, in Wuhan, China and later as a pandemic on March 11, 2020 [2]. India is also in the thick of this highly infectious viral disease with over 70,000 people caught in its tentacles (as on May 12,2020) [3].

The symptoms of COVID-19 range from mild to severe, which are indicated by mainly fever, cough, and respiratory distress. The two most important modes of transmission of corona virus are respiratory droplets and contact transmission (contaminated hands) with an incubation period 2-14 days [4-5]. The virus spread rapidly around the world and several large-size clusters of the spread have been observed worldwide including outbreaks in China, USA, Spain, Russia, UK, Italy and India. Despite strong interventions including country wide lockdowns by governments of many countries, this pandemic is nowhere near full control in most of the countries except China and South Korea.

In the absence of a COVID 19 vaccine at the moment the only accepted way to attenuate the growth is to practice good hand hygiene, using masks compulsorily and social distancing. In an effort to contain this epidemic's spread in India, the Indian Prime Minister also announced a nation-wide lockdown from the midnight of 24th March 2020 and subsequent series of lockdowns to prevent spreading of the virus from human-to-human transmission. Since these measures have brought huge pressure on economy, it is not only important to contain the spread 
medRxiv preprint doi: https://doi.org/10.1101/2020.05.14.20101725; this version posted May 19, 2020. The copyright holder for this preprint (which was not certified by peer review) is the author/funder, who has granted medRxiv a license to display the preprint in perpetuity.

It is made available under a CC-BY-NC-ND 4.0 International license .

of the Coronavirus but also to have quantitative estimates of the spread or its abetment to estimate its impact and to plan economic and health policies to reduce the shock on economy.

Indian Government has been proactive since the end of January 2020, when the first case of infected person was detected in Kerala. Indian government had taken preventive measures well in time by announcing nationwide lockdown on $22^{\text {nd }}$ March 2020 and its $4^{\text {th }}$ phase, Lockdown 4.0, is going to start from $18^{\text {th }}$ of May 2020. Detailed measures [3] such as screening of passengers at airport, restricting public gatherings, suspension of transport including flights, trains and buses, increasing quarantine facility, dedicated COVID-19 hospitals, increasing sample testing etc. were taken by the government during Lockdown period. To revive the economy, Prime minister Modi has announced a package of Rs. 20 lakh crores (20 trillion) on $12^{\text {th }}$ May 2020.

Many studies have been recently reported by researchers to understand the dynamics of this pandemic [6-11]. The forecast of COVID-19 in the context of India has been investigated by many researchers using mathematical [12-16] and epidemiological [17-19] models but have limited studies [20-21] of individual states. Looking at the demographical and geographical diversity in India, a separate state-wise study of COVID-19 epidemic is the need of the hour.

In this paper, we present a study of epidemiological Susceptible-Infected-Recovered (SIR) model [22] for the spread of COVID-19 in various states of India. It is worth mentioning here that the forecasts using this model are as good as the quality of data available and, therefore, the progress of the spread of the virus may also affect the predictions [23]. 
medRxiv preprint doi: https://doi.org/10.1101/2020.05.14.20101725; this version posted May 19, 2020. The copyright holder for this preprint (which was not certified by peer review) is the author/funder, who has granted medRxiv a license to display the preprint in perpetuity.

It is made available under a CC-BY-NC-ND 4.0 International license .

\section{Methods}

The SIR model is one of the simplest compartmental models which consists of threecompartment levels: Susceptible (S), Infectious (I) and Removed (R)[22]. S represents those peoples who have no immunity to the disease but they are not infectious and can be represented by the entire population, I are those who have already contracted the disease, and the $\mathrm{R}$ represents the recovered and diseased peoples. Also, it assumes that within the outbreak period, no significance population change takes place (e.g., through new births, deaths, migration etc.) and $\mathrm{N}=\mathrm{S}+\mathrm{I}+\mathrm{R}=$ Constant. The SIR model can be expressed by the following set of ordinary differential equations [24]:

$$
\begin{aligned}
& \frac{d S}{d t}=-\frac{\beta I S}{N} \\
& \frac{d I}{d t}=-\frac{\beta I S}{N}-\gamma I \\
& \frac{d R}{d t}=-\gamma I
\end{aligned}
$$

Where, $t$ is time, $S(t)$ is the number of susceptible persons at time $t, I=I(t)$ is the number of infected persons at time $t, R(t)$ is the number of recovered persons in time $t, \beta$ is the contact rate, and $1 / \gamma$ is the average infectious period. In particular, the model with three equations can be reduced to one function about the total infection count $(C=I+R)[25]$. In our study, the epidemiological data has been collected from official website of Ministry of Health and Family Welfare, Government of India (https://www.mohfw.gov.in) till $12^{\text {th }}$ May 2020 from the date of first case detected in each state. The simulations of SIR model are performed using fminsearch and ode45 functions of MATLAB as implemented by M. Batista in references [26-27]. 
medRxiv preprint doi: https://doi.org/10.1101/2020.05.14.20101725; this version posted May 19, 2020. The copyright holder for this preprint (which was not certified by peer review) is the author/funder, who has granted medRxiv a license to display the preprint in perpetuity.

\section{Results and Discussion}

The cumulative number of infected peoples in the states under consideration varies from $\sim 50$ to $\sim 25,000$. Maharashtra has recorded highest number of infected peoples (24427) till $12^{\text {th }}$ May 2020, followed by 8904 in Gujrat, 8718 in Tamil Nadu and 7639 in Delhi. The states like Rajasthan, Madhya Pradesh, Uttar Pradesh, West Bengal, Punjab and Andhra Pradesh have number of cases in the range of $1000-5000$ on $12^{\text {th }}$ May 2020 whereas rest of the states have less than 1000 cases. Kerala is the only state in India, which seems to be in total control over COVID-19 epidemic.

The results of the calculation are shown in Table 1 and in Figures1-5. We consider different states in descending order of the number of cumulative infected cases. For each state we have calculated $\mathrm{R}_{0}$ (basic reproduction number), $\beta$ (Average contact frequency), $\gamma$ (average removal frequency), $\mathrm{C}_{\{\text {end }\}}$ (epidemic size), and $\mathrm{S}_{\{\text {end\} }}$ (final number of susceptible individuals left) with the four periods of infection i.e. (i) start of acceleration, (ii) start of steady growth, (iii) start of ending phase and (iv) end of epidemic (1 case). In the figure for each state, we present two graphs: one is total number of novel Corona cases per day and second is the different epidemic phases i.e. initial exponential growth, fast growth, asymptotic slow growth and curve flattening. The statistical parameters such as coefficient of determination $\left(R^{2}\right)$, adjusted $R^{2}$, p-value, root mean square error (RMSE) and F-statistics vs zero model for each state are listed in Table 2. The coefficient of determination $\left(\mathrm{R}^{2}\right)$ and $\mathrm{p}$-value of the model for most of the states are close to 1 and 0 , respectively, indicating high statistical significance of the results.

According to our prediction for India from data up to $12^{\text {th }}$ May 2020, the curve flattening of epidemic will start from first week of July and the epidemic may end by the third week of 
medRxiv preprint doi: https://doi.org/10.1101/2020.05.14.20101725; this version posted May 19, 2020. The copyright holder for this preprint (which was not certified by peer review) is the author/funder, who has granted medRxiv a license to display the preprint in perpetuity. It is made available under a CC-BY-NC-ND 4.0 International license .

October (Figure 1). The calculated value of $\mathrm{R}_{0}$ is 1.15 and the epidemic size (number of infected peoples) is estimated to be $1,76,126$. The coefficient of determination, $\mathrm{R}^{2}=0.998$, and $\mathrm{p}$-value close to zero indicates the statistical significance of our predicted results from epidemiological data of India. Note that number of cumulative cases up to $1^{\text {st }}$ May 2020 in India was predicted to be $\sim 36,000$ in recent study [21]. Also, the value of $\mathrm{R}_{0}$ is calculated as 1.50 [17] and 2.02 [27] in recent studies.

Among all the Indian states, Maharashtra is severely affected by COVID-19 epidemic. The SIR model indicates that the acceleration period of infection is from 25-Apr-2020 to 26June-2020.The ending phase of epidemic may occur in the last week of June and it may be finished by the second week of September with epidemic size of 55,631(Figure 2). The calculated value of $R_{0}$ is 1.11 with $R^{2}$ and $p$-value close to 1 and 0 , respectively. Note that number of cumulative cases up to $1^{\text {st }}$ May 2020 for Maharashtra was predicted to be $\sim 9,800$ in recent study [21].

Another important state is Punjab, where according to media reports over 90,000 NRI returned to Punjab from abroad in the first quarter of the year 2020 [28]. The model indicates that the fast growth of infection is from $27^{\text {th }}$ April 2020 to $2^{\text {nd }}$ June 2020, thereafter, curve flattening will start and the epidemic is expected to finished by the first week of July (Figure 3). The estimated number of infected peoples is 3237 . The calculated value of $R_{0}$ is 1.28 which is little higher than country (1.15). The statistical parameter $\mathrm{R}^{2}$ is calculated to be 0.964 and $\mathrm{p}$ value is close to zero. Our study suggests that Punjab has relatively good control over the epidemic which may be due to the strict prevention measures taken during curfew imposed by Punjab government since $22^{\text {nd }}$ March 2020 in whole state. 
medRxiv preprint doi: https://doi.org/10.1101/2020.05.14.20101725; this version posted May 19, 2020. The copyright holder for this preprint (which was not certified by peer review) is the author/funder, who has granted medRxiv a license to display the preprint in perpetuity. It is made available under a CC-BY-NC-ND 4.0 International license .

The predicted data for other states is tabulated in Table 1 and plotted in Figures 2-5. The epidemic in Kerala is in its final phase and is expected to end by first week of June. Other states such as Telangana and Jharkhand are predicted to get rid of COVID-19 by the end of June. The states like Delhi, West Bengal, Odisha have to wait for the end of this epidemic up to midOctober, end of November and first week of December, respectively. The epidemic size of COVID-19 outbreak in Delhi, West Bengal, Gujrat, Tamil Nadu and Odisha can reach as large as $23,635,17,522,16,409,12,555$ and 10,921 , respectively. The $\mathrm{R}_{0}$ for various states varies from 1.03 in Uttarakhand to 7.92 in Bihar. Note that in recent study, the daily infection rate (DIR) of COVID-19 for Maharashtra, Delhi Gujrat, Madhya Pradesh, Andhra Pradesh, Uttar Pradesh and West Bengal has shown exponential growth [20].

The calculated value of $\mathrm{R}^{2}$ for Assam (0.506) and Himachal Pradesh (0.868) is lower than the desirable value. This indicates a small correlation between the predicted and actual numbers of the epidemic, which is due to the small number and large fluctuation of epidemiological data. The epidemic in these states were expected to end in April, however, increased number of cases have been reported in last few days (Figure 5), which are attributed to the interstate movement of significant number of migrants in these states [29]. Considering the strict prevention measures, this rise in cases is momentarily and these states are expected to mitigate the epidemic in coming days.

It is worth discussing on the number of samples tested for COVID-19 cases around the country. As on 12 May 2020, a total number of 17,59,589 samples have been tested throughout the country out of which 74,329 samples were tested positive which comes out to be $4.22 \%$ of total collected samples [30]. The \% of positive cases in Karnataka, Odisha, Jharkhand, Uttarakhand, Himachal Pradesh and Assam is $<1 \%$. The total confirmed cases, total samples 
medRxiv preprint doi: https://doi.org/10.1101/2020.05.14.20101725; this version posted May 19, 2020. The copyright holder for this preprint (which was not certified by peer review) is the author/funder, who has granted medRxiv a license to display the preprint in perpetuity.

It is made available under a CC-BY-NC-ND 4.0 International license .

tested and $\%$ of positive cases are listed in Table 3. In Maharashtra, percentage of positive cases is highest with $10.98 \%$ followed by Gujrat (7.45\%), Delhi (7.19\%) and Madhya Pradesh $(4.92 \%)$. The greater number of testing in these states may be required in coming days and the predicted results for these states may change in near future.

\section{Conclusions}

In summary, classical SIR epidemiological model has been used to predict the COVID19 outbreak in India and its different states. The value of $\mathrm{R}_{0}$ is calculated to be 1.15 for Indian population. Among Indian states, Maharashtra is severely affected where the ending phase of epidemic may occur in the last week of June and it may be ended by the second week of September. The model indicates that the curve flattening in Punjab may start in the first week of June up to first week of July. The states like Delhi, West Bengal, Odisha have to wait for the end of this epidemic up to mid-October, end of November and first week of December, respectively. These predictions are based on the assumptions that the current preventive efforts will be continue. In Maharashtra, percentage of positive cases with respect to total sample collected is highest with $10.98 \%$ followed by Gujrat (7.45\%), Delhi (7.19\%) and Madhya Pradesh (4.92\%), which are higher than the percentage of country (4.22\%). 
medRxiv preprint doi: https://doi.org/10.1101/2020.05.14.20101725; this version posted May 19, 2020. The copyright holder for this preprint (which was not certified by peer review) is the author/funder, who has granted medRxiv a license to display the preprint in perpetuity.

It is made available under a CC-BY-NC-ND 4.0 International license .

Table 1. The various parameters calculated using $\operatorname{SIR}$ model. $\mathrm{R}_{0,} \beta, \gamma, \mathrm{C}_{\{\text {end }\}}$ and $\mathrm{S}_{\{\mathrm{end}\}}$ represent basic reproduction number, average contact frequency, average removal frequency, epidemic size and final number of susceptible individuals left.

\begin{tabular}{|c|c|c|c|c|c|c|c|c|c|c|}
\hline $\begin{array}{c}\text { India and } \\
\text { State }\end{array}$ & $\mathbf{R}_{\mathbf{0}}$ & $\boldsymbol{\beta}$ & $\gamma$ & $\mathbf{C}_{\{\text {end }\}}$ & $\mathbf{S}_{\{\text {end }\}}$ & $\begin{array}{c}\text { Outbreak } \\
\text { (year-2020) }\end{array}$ & $\begin{array}{c}\text { Start of } \\
\text { acceleration } \\
\text { (year-2020) }\end{array}$ & $\begin{array}{c}\text { Start of } \\
\text { steady } \\
\text { growth } \\
\text { (year-2020) }\end{array}$ & $\begin{array}{c}\text { Start of } \\
\text { ending } \\
\text { phase } \\
\text { (year-2020) }\end{array}$ & $\begin{array}{c}\text { End of } \\
\text { epidemic } \\
(1 \text { case }) \\
(\text { year-2020 })\end{array}$ \\
\hline India & 1.15 & 0.66 & 0.573 & 176126 & 523659 & 03-Mar & 23-Apr & 10-Jun & 04-Jul & 16-Oct \\
\hline Maharashtra & 1.11 & 1.008 & 0.908 & 55631 & 234823 & 11-Mar & 25-Apr & 05-Jun & 26-Jun & 09-Sep \\
\hline Gujrat & 1.58 & 0.282 & 0.179 & 16409 & 9558 & 20-Mar & 19-Apr & 01-Jun & 22-Jun & 13-Sep \\
\hline Tamil Nadu & 3.1 & 0.371 & 0.12 & 12555 & 701 & 18-Mar & 03-May & 20-May & 29-May & 29-Jul \\
\hline Delhi & 1.19 & 0.486 & 0.409 & 23635 & 55146 & 03-Mar & 26-Apr & 19-Jun & 16-Jul & 15-Oct \\
\hline Rajasthan & 1.72 & 0.269 & 0.156 & 4900 & 2080 & 03-Mar & 09-Apr & 19-May & 08-Jun & 13-Aug \\
\hline $\begin{array}{l}\text { Madhya } \\
\text { Pradesh }\end{array}$ & 1.68 & 0.347 & 0.206 & 4053 & 1866 & 22-Mar & 09-Apr & 11-May & 27-May & 16-Jul \\
\hline Uttar Pradesh & 1.77 & 0.273 & 0.154 & 4531 & 1748 & 04-Mar & 11-Apr & 19-May & 07-Jun & 10-Aug \\
\hline West Bengal & 1.96 & 0.18 & 0.092 & 17522 & 4751 & 19-Mar & 11-May & 01-Jul & 26-Jul & 24-Nov \\
\hline $\begin{array}{l}\text { Andhra } \\
\text { Pradesh }\end{array}$ & 1.12 & 0.979 & 0.874 & 2500 & 9462 & 19-Mar & 09-Apr & 17-May & 05-Jun & 15-Jul \\
\hline Punjab & 1.28 & 0.797 & 0.621 & 3237 & 4708 & 18-Mar & 27-Apr & 21-May & 02-Jun & 01-Jul \\
\hline Telangana & 2.44 & 0.298 & 0.122 & 1180 & 153 & 14-Mar & 31-Mar & 26-Apr & 09-May & 22-Jun \\
\hline $\begin{array}{c}\text { Jammu and } \\
\text { Kashmir }\end{array}$ & 1.41 & 0.275 & 0.195 & 1330 & 1211 & 13-Mar & 06-Apr & 28-May & 24-Jun & 19-Aug \\
\hline Karnataka & 1.09 & 0.789 & 0.723 & 1216 & 6031 & 12-Mar & 03-Apr & 30-May & 28-Jun & 16-Aug \\
\hline Bihar & 7.92 & 0.18 & 0.023 & 823 & 0 & 23-Mar & 18-Apr & 15-May & 28-May & 17-Jul \\
\hline Kerala & 2.55 & 0.271 & 0.106 & 494 & 55 & 05-Mar & 19-Mar & 16-Apr & 30-Apr & 06-Jun \\
\hline Odisha & 1.74 & 0.19 & 0.109 & 10921 & 4449 & 21-Mar & 28-May & 22-Jul & 19-Aug & 05-Dec \\
\hline Jharkhand & 1.86 & 0.298 & 0.16 & 191 & 61 & 02-Apr & 14-Apr & 16-May & 31-May & 22-Jun \\
\hline Tripura & 1.87 & 2.101 & 1.123 & 148 & 47 & 10-Apr & 06-May & 11-May & 13-May & 16-May \\
\hline Uttarakhand & 1.03 & 2.264 & 2.204 & 71 & 1071 & 20-Mar & 24-Mar & 06-May & 27-May & 04-Jun \\
\hline Assam & 3.44 & 0.969 & 0.281 & 41 & 1 & 01-Apr & 03-Apr & 09-Apr & 12-Apr & 14-Apr \\
\hline $\begin{array}{c}\text { Himachal } \\
\text { Pradesh }\end{array}$ & 3.23 & 0.696 & 0.215 & 36 & 2 & 22-Mar & 04-Apr & 13-Apr & 18-Apr & 20-Apr \\
\hline Chhattisgarh & 1.23 & 0.259 & 0.211 & 83 & 132 & 24-Mar & 26-Mar & 25-May & 24-Jun & 14-Jul \\
\hline
\end{tabular}


medRxiv preprint doi: https://doi.org/10.1101/2020.05.14.20101725; this version posted May 19, 2020. The copyright holder for this preprint (which was not certified by peer review) is the author/funder, who has granted medRxiv a license to display the preprint in perpetuity.

It is made available under a CC-BY-NC-ND 4.0 International license .

Table2: Statistics of SIR model for India and its various states.

\begin{tabular}{|c|c|c|c|c|c|c|c|}
\hline India and State & $\begin{array}{c}\text { Number of } \\
\text { observations }\end{array}$ & $\begin{array}{l}\text { Degrees of } \\
\text { freedom }\end{array}$ & RMSE & $\mathbf{R}^{2}$ & $\begin{array}{l}\text { Adjusted R- } \\
\text { Squared }\end{array}$ & $\begin{array}{c}\text { F-statistics vs. } \\
\text { zero model }\end{array}$ & p-value \\
\hline India & 71 & 67 & 924 & 0.998 & 0.998 & 10131.5 & $7.90173 \mathrm{e}-88$ \\
\hline Maharashtra & 63 & 59 & 243 & 0.999 & 0.999 & 14329.8 & $2.14263 \mathrm{e}-84$ \\
\hline Gujrat & 54 & 50 & 277 & 0.989 & 0.989 & 1610.48 & $1.03819 \mathrm{e}-49$ \\
\hline Tamil Nadu & 56 & 52 & 1084 & 0.703 & 0.679 & 51.9686 & $1.14244 \mathrm{e}-15$ \\
\hline Delhi & 71 & 67 & 147 & 0.995 & 0.995 & 4286.36 & $1.81163 \mathrm{e}-76$ \\
\hline Rajasthan & 71 & 67 & 79 & 0.996 & 0.996 & 5611.5 & $2.27489 \mathrm{e}-80$ \\
\hline Madhya Pradesh & 52 & 48 & 105 & 0.933 & 0.930 & 703.996 & $5.5109 \mathrm{e}-34$ \\
\hline Uttar Pradesh & 70 & 66 & 45 & 0.998 & 0.998 & 14179.8 & $1.22704 \mathrm{e}-92$ \\
\hline West Bengal & 55 & 51 & 40 & 0.995 & 0.995 & 3552.06 & $3.52659 \mathrm{e}-59$ \\
\hline Andhra Pradesh & 55 & 51 & 35 & 0.998 & 0.997 & 6742.15 & $2.99025 \mathrm{e}-66$ \\
\hline Punjab & 56 & 52 & 108 & 0.964 & 0.961 & 506.256 & $1.88912 \mathrm{e}-38$ \\
\hline Telangana & 60 & 56 & 34 & 0.995 & 0.994 & 3415.41 & $2.33263 e-63$ \\
\hline $\begin{array}{l}\text { Jammu and } \\
\text { Kashmir }\end{array}$ & 61 & 57 & 29 & 0.99 & 0.99 & 1977.92 & $1.4714 \mathrm{e}-57$ \\
\hline Karnataka & 62 & 58 & 19 & 0.995 & 0.994 & 3599.05 & $7.83511 \mathrm{e}-66$ \\
\hline Bihar & 51 & 47 & 26 & 0.987 & 0.986 & 1228.3 & $1.24776 \mathrm{e}-44$ \\
\hline Kerala & 69 & 65 & 22 & 0.987 & 0.987 & 1635.79 & $3.90792 \mathrm{e}-61$ \\
\hline Odisha & 53 & 49 & 21 & 0.956 & 0.952 & 370.222 & $1.19745 \mathrm{e}-33$ \\
\hline Jharkhand & 41 & 37 & 7 & 0.985 & 0.984 & 827.057 & $6.07144 \mathrm{e}-34$ \\
\hline Tripura & 33 & 29 & 12 & 0.935 & 0.926 & 113.566 & $3.96801 \mathrm{e}-16$ \\
\hline Uttarakhand & 53 & 49 & 4 & 0.975 & 0.973 & 627.915 & $1.16588 \mathrm{e}-39$ \\
\hline Assam & 42 & 38 & 10 & 0.506 & 0.453 & 19.5462 & $7.88278 \mathrm{e}-08$ \\
\hline Himachal Pradesh & 52 & 48 & 7 & 0.868 & 0.856 & 100.349 & $1.09406 \mathrm{e}-20$ \\
\hline Chhattisgarh & 50 & 46 & 5 & 0.925 & 0.918 & 191.294 & $5.55392 \mathrm{e}-26$ \\
\hline
\end{tabular}


medRxiv preprint doi: https://doi.org/10.1101/2020.05.14.20101725; this version posted May 19, 2020. The copyright holder for this preprint (which was not certified by peer review) is the author/funder, who has granted medRxiv a license to display the preprint in perpetuity.

It is made available under a CC-BY-NC-ND 4.0 International license .

Table 3: Number of confirmed cases, number of samples tested and \% of positive cases in India and various states as on $12^{\text {th }}$ May 2020 [30].

\begin{tabular}{|c|c|c|c|}
\hline India and State & Confirmed Cases & Samples Tested & $\begin{array}{c}\% \text { of Positive Cases from } \\
\text { Tested Samples }\end{array}$ \\
\hline India & 74329 & 1759579 & 4.224249 \\
\hline Maharashtra & 24427 & 222284 & 10.9891 \\
\hline Gujrat & 8904 & 119536 & 7.448802 \\
\hline Tamil Nadu & 8718 & 266687 & 3.269001 \\
\hline Delhi & 7639 & 106109 & 7.199201 \\
\hline Rajasthan & 4126 & 185610 & 2.222941 \\
\hline Madhya Pradesh & 3986 & 80885 & 4.927984 \\
\hline Uttar Pradesh & 3664 & 140166 & 2.614043 \\
\hline West Bengal & 2173 & 52622 & 4.129452 \\
\hline Andhra Pradesh & 2089 & 191874 & 1.088735 \\
\hline Punjab & 1914 & 43999 & 4.350099 \\
\hline Telangana & 1326 & Not available & Not available \\
\hline Jammu and Kashmir & 934 & 53726 & 1.738451 \\
\hline Karnataka & 925 & 116533 & 0.793767 \\
\hline Bihar & 879 & 37430 & 2.348384 \\
\hline Haryana & 780 & 62377 & 1.250461 \\
\hline Kerala & 525 & 38547 & 1.361974 \\
\hline Odisha & 437 & 66057 & 0.66155 \\
\hline Jharkhand & 172 & 22815 & 0.75389 \\
\hline Tripura & 153 & 10344 & 1.479118 \\
\hline Uttarakhand & 69 & 10471 & 0.658963 \\
\hline Assam & 65 & 21791 & 0.298288 \\
\hline Himachal Pradesh & 66 & 12224 & 0.539921 \\
\hline Chhattisgarh & 59 & 27339 & 0.215809 \\
\hline
\end{tabular}


medRxiv preprint doi: https://doi.org/10.1101/2020.05.14.20101725; this version posted May 19, 2020. The copyright holder for this preprint (which was not certified by peer review) is the author/funder, who has granted medRxiv a license to display the preprint in perpetuity.

It is made available under a CC-BY-NC-ND 4.0 International license .
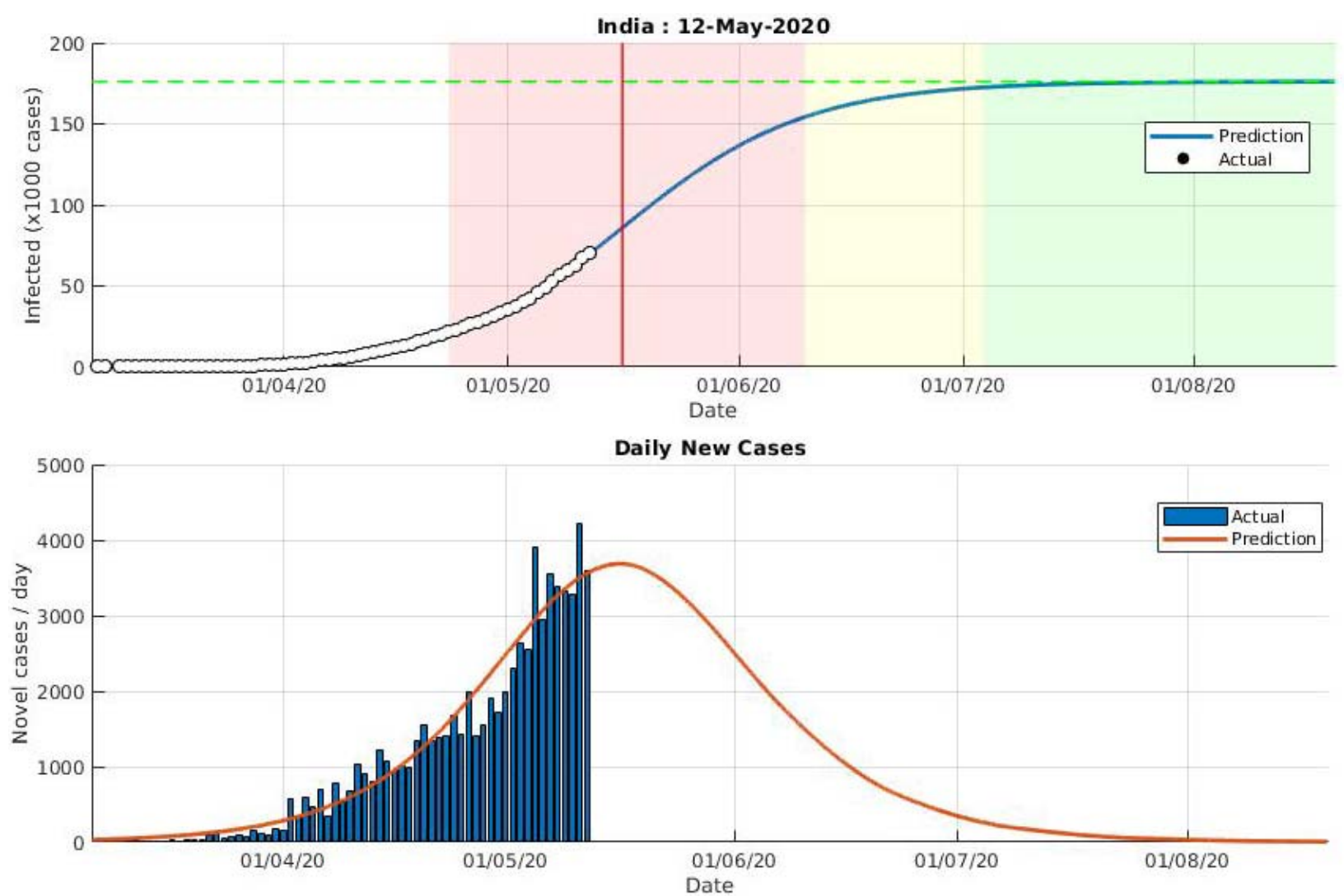

Figure 1: Predictions using SIR model for India using data upto $12^{\text {th }}$ May 2020. The different epidemic phases are shown with white, red, yellow and green colors which represent initial exponential growth, fast growth (with positive and negative phase separated by red vertical line), asymptotic slow growth and curve flattening, respectively. 
medRxiv preprint doi: https://doi.org/10.1101/2020.05.14.20101725; this version posted May 19, 2020. The copyright holder for this preprint (which was not certified by peer review) is the author/funder, who has granted medRxiv a license to display the preprint in perpetuity.

It is made available under a CC-BY-NC-ND 4.0 International license .
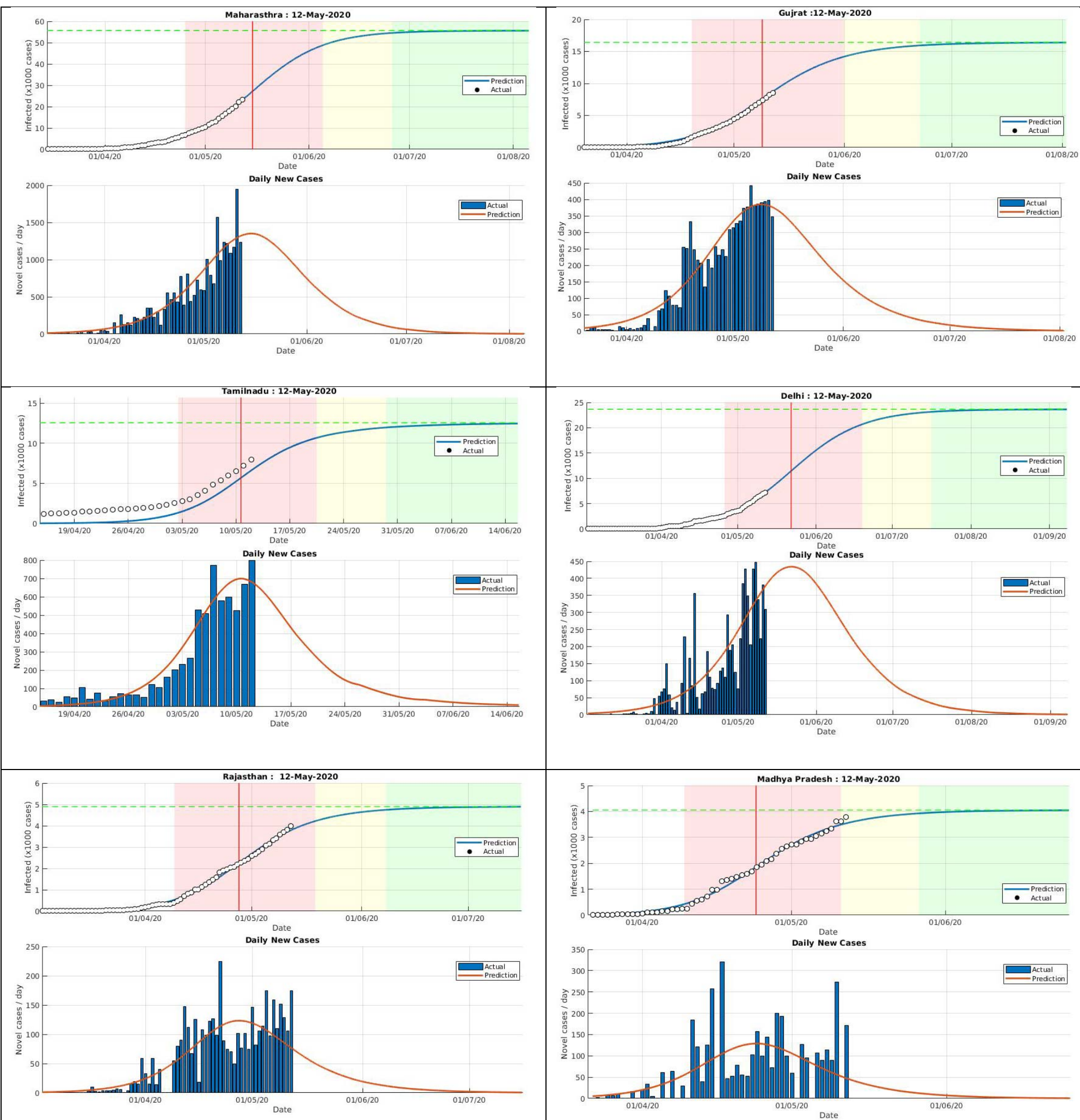

Figure 2: Predictions for various states (Maharashtra, Gujrat, Tamil Nadu, Delhi, Rajsthan and Madhya Pradesh) using SIR model. The different epidemic phases are shown with white, red, yellow and green colors which represent initial exponential growth, fast growth (with positive and negative phase separated by red vertical line), asymptotic slow growth and curve flattening, respectively. 
medRxiv preprint doi: https://doi.org/10.1101/2020.05.14.20101725; this version posted May 19, 2020. The copyright holder for this preprint (which was not certified by peer review) is the author/funder, who has granted medRxiv a license to display the preprint in perpetuity.

It is made available under a CC-BY-NC-ND 4.0 International license.
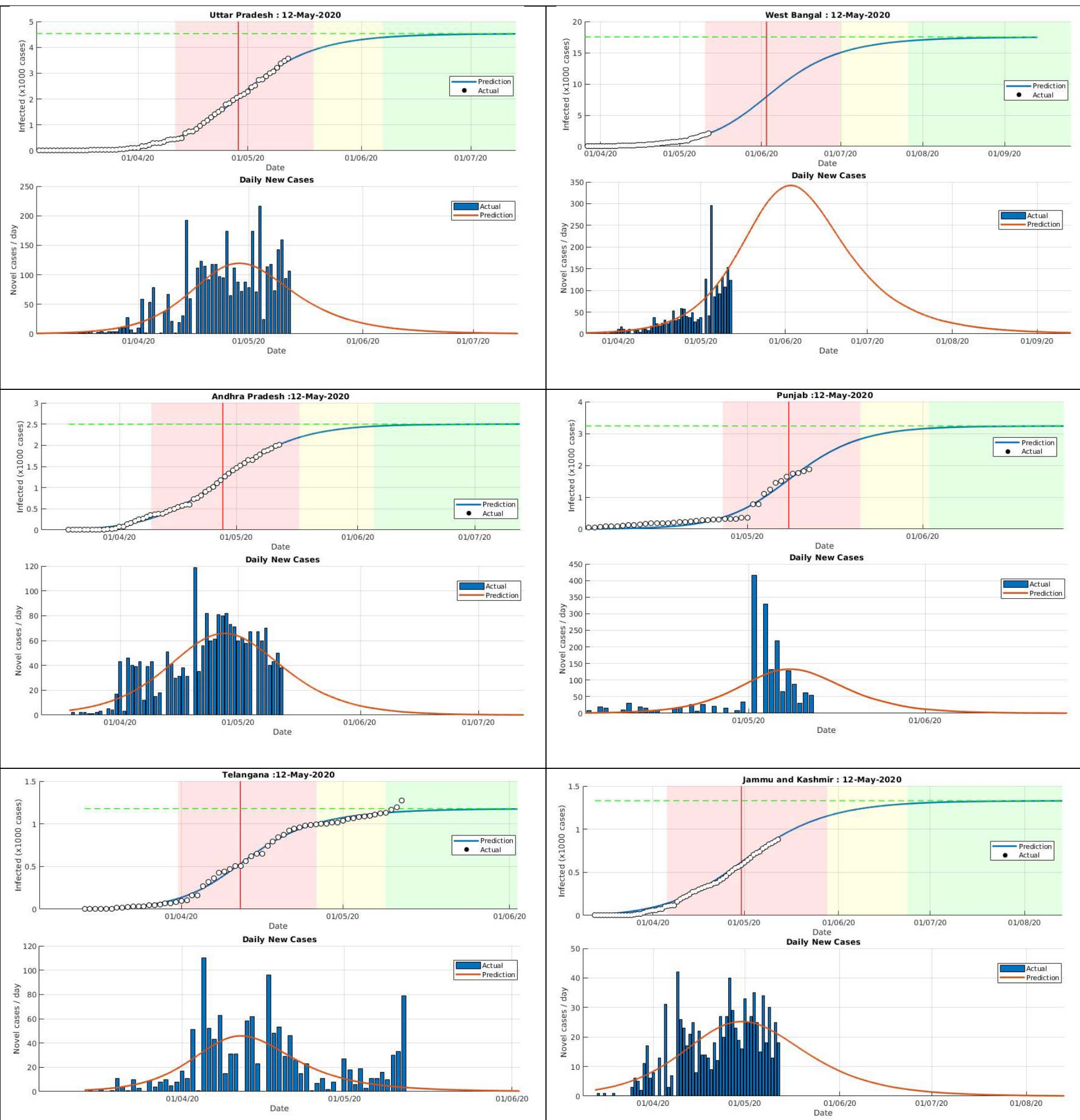

Figure 3: Predictions for various states (Uttar Pradesh, West Bangal, Andhra Pradesh, Punjab, Telangana, Jammu and Kashmir) using SIR model. The different epidemic phases are shown with white, red, yellow and green colors which represent initial exponential growth, fast growth (with positive and negative phase separated by red vertical line), asymptotic slow growth and curve flattening, respectively. 
medRxiv preprint doi: https://doi.org/10.1101/2020.05.14.20101725; this version posted May 19, 2020. The copyright holder for this preprint (which was not certified by peer review) is the author/funder, who has granted medRxiv a license to display the preprint in perpetuity.

It is made available under a CC-BY-NC-ND 4.0 International license.
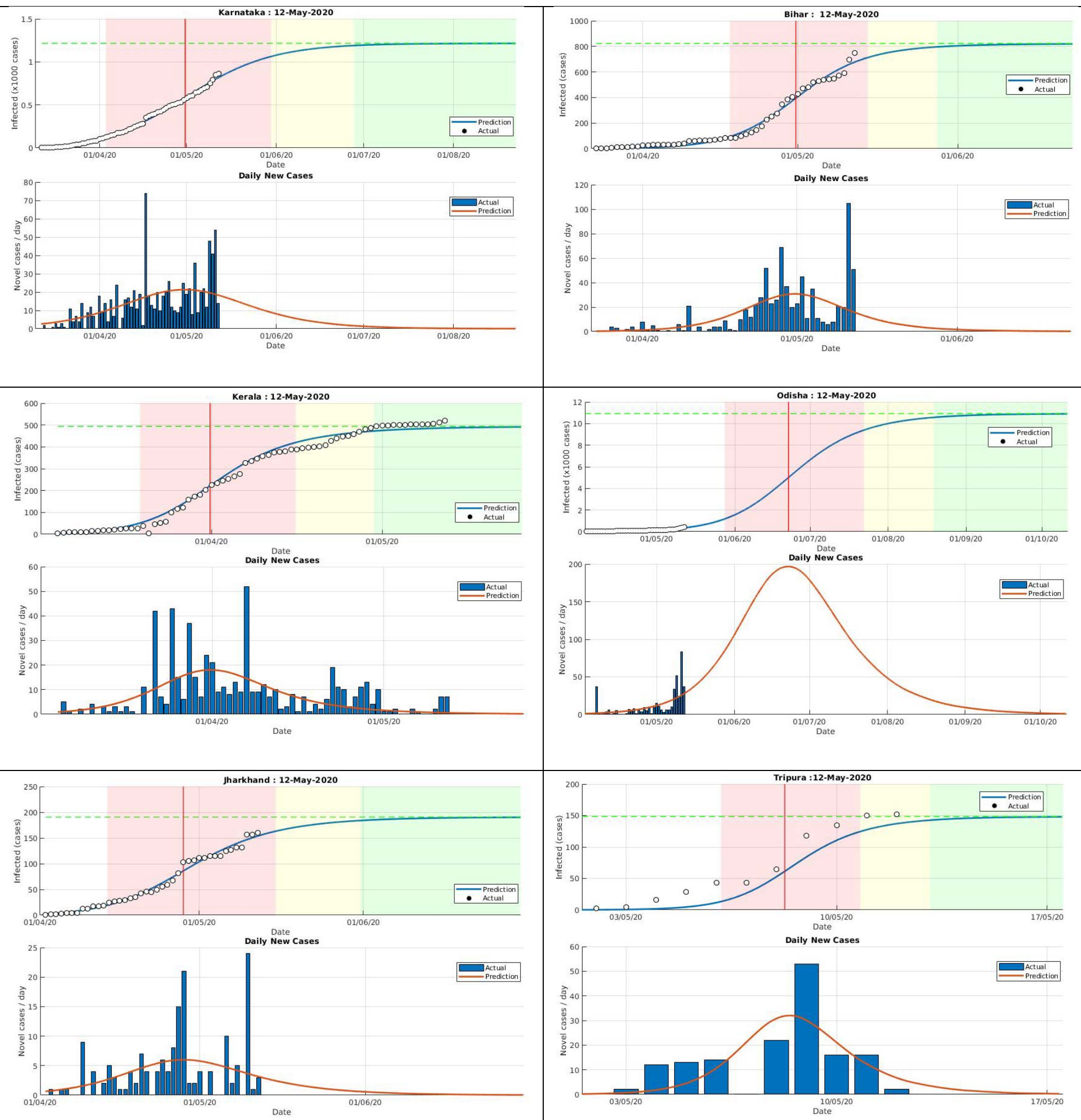

Figure 4: Predictions for various states (Karnatks, Bihar, Kerala, Odisha, Jharkhand and Tripura) using SIR model. The different epidemic phases are shown with white, red, yellow and green colors which represent initial exponential growth, fast growth (with positive and negative phase separated by red vertical line), asymptotic slow growth and curve flattening, respectively. 
medRxiv preprint doi: https://doi.org/10.1101/2020.05.14.20101725; this version posted May 19, 2020. The copyright holder for this preprint (which was not certified by peer review) is the author/funder, who has granted medRxiv a license to display the preprint in perpetuity.

It is made available under a CC-BY-NC-ND 4.0 International license .

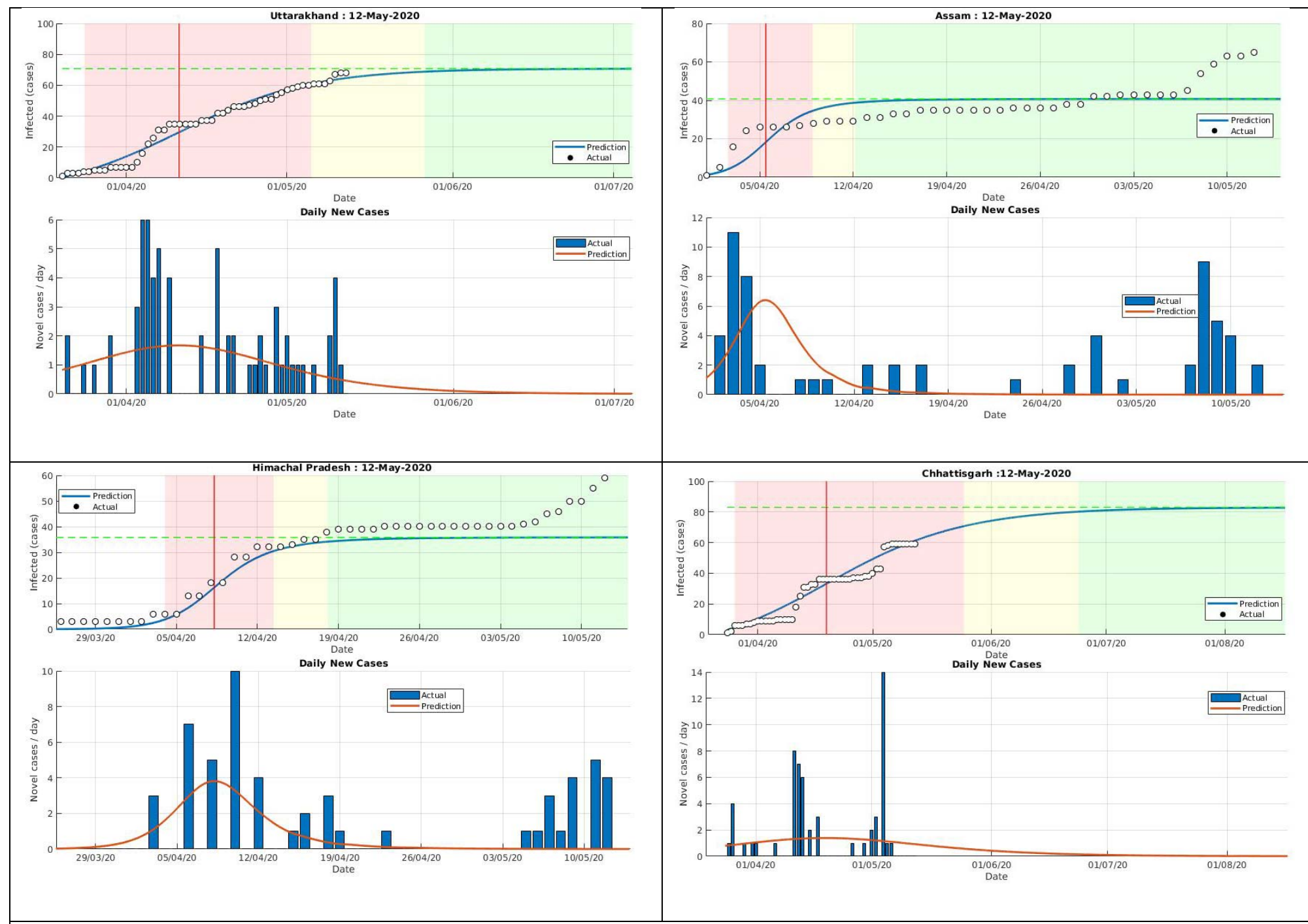

Figure 5: Predictions for various states (Uttarakhand Assam, Himachal Pradesh and Chhattisgarh) using SIR model. The different epidemic phases are shown with white, red, yellow and green colors which represent initial exponential growth, fast growth (with positive and negative phase separated by red vertical line), asymptotic slow growth and curve flattening, respectively.

\section{Acknowledgement}

We acknowledge Prof. Milan Batista, University of Ljubljana, Slovenia for helpful discussion regarding technicalities of the method used in this study.

\section{References}

1. Situation report-113: Available at https://www.who.int/docs/defaultsource/coronaviruse/situation-reports/. 
medRxiv preprint doi: https://doi.org/10.1101/2020.05.14.20101725; this version posted May 19, 2020. The copyright holder for this preprint (which was not certified by peer review) is the author/funder, who has granted medRxiv a license to display the preprint in perpetuity. It is made available under a CC-BY-NC-ND 4.0 International license .

2. W.H. O, Statement on the second meeting of the International Health Regulations (2005) Emergency Committee regarding the outbreak of novel coronavirus (2019-nCoV). 2020.

3. https://www.mohfw.gov.in/dashboard/index.php . Accessed on May 12,2020

4. T. Singhal, A review of coronavirus disease-2019 (COVID-19). The Indian Journal of Pediatrics, 2020: p. 1-6.

5. J.F.-W Chan et al., A familial cluster of pneumonia associated with the 2019 novel coronavirus indicating person-to-person transmission: a study of a family cluster. The Lancet, 2020. 395(10223): p. 514-523.

6. M. A. A. Al-qaness et. al., Optimization Method for Forecasting Confirmed Cases of COVID19 in China, J. Clin. Med, 9, 674 (2020)

7. S. Ansumal et. al.,A Very Flat Peak: Exponential growth phase of COVID-19 is mostly followed by a prolonged linear growth phase, not an immediate saturation, medRxiv 2020:https://doi.org/10.1101/2020.04.07.20055772

8. S. K. Bandyopadhyay et. al.,Machine Learning Approach for Confirmation of COVID-19 Cases: Positive, Negative, Death and medRxiv 2020:https://doi.org/10.1101/2020.03.25.20043505

9. C. P. Vyasarayani et. al., New approximations, and policy implications, from a delayed dynamic model of a fast pandemic, arXiv preprint 2020: arXiv:2004.03878v1 [q-bio.PE]

10. K. Biswas et. al., Covid-19 spread: Reproduction of data and prediction using a SIR model on Euclidean network, arXiv preprint 2020: arXiv:2003.07063v1 [physics.soc-ph]

11. M. Chinazziet al., The effect of travel restrictions on the spread of the 2019 novel coronavirus (COVID-19) outbreak, Science,DOI: 10.1126/science.aba9757 (2020).

12. P. Kumar et. al., Forecasting COVID-19 impact in India using pandemic waves Nonlinear 
medRxiv preprint doi: https://doi.org/10.1101/2020.05.14.20101725; this version posted May 19, 2020. The copyright holder for this preprint (which was not certified by peer review) is the author/funder, who has granted medRxiv a license to display the preprint in perpetuity. It is made available under a CC-BY-NC-ND 4.0 International license .

Growth Models, medRxiv 2020: https://doi.org/10.1101/2020.03.30.20047803

13. M. K. Prakash et. al.,A minimal and adaptive prediction strategy for critical resource planning in a pandemic, medRxiv 2020: https://doi.org/10.1101/2020.04.08.20057414

14. S. Mondal et. al., Possibilities of exponential or Sigmoid growth of Covid19 data in different states of India, medRxiv 2020: https://doi.org/10.1101/2020.04.10.20060442

15. J. S.Virk et. al., Recent update on COVID-19 in India: Is locking down the country enough? medRxiv 2020: $\underline{\text { https://doi.org/10.1101/2020.04.06.20053124 }}$

16. R. Singh et. al., Age-structured impact of social distancing on the COVID-19 epidemic in India, arXiv preprint 2020: arXiv:2003.12055v1 [q-bio.PE]

17. R. Ranjan, Predictions for COVID-19 outbreak in India using Epidemiological models, medRxiv 2020:https://doi.org/10.1101/2020.04.02.20051466

18. S. Mandal et. al., Prudent public health intervention strategies to control the coronavirus disease 2019 transmission in India: A mathematical model-based approach, Indian J. Med. Res (2020): DOI: 10.4103/ijmr.IJMR_504_20

19. T. Sardar et. al., Assessment of 21 Days Lockdown Effect in Some States and Overall India: A Predictive Mathematical Study on COVID-19Outbreak, arXiv preprint 2020:arXiv:2004.03487v1 [q-bio.PE]

20. P. Ghosh et. al., COVID-19 in India: State-wise Analysis and Prediction, medRxiv 2020: https://doi.org/10.1101/2020.04.24.20077792

21. N. Poonia and S. Azad, Short-term forecasts of COVID-19 spread across Indian states until 1 May 2020, https://arxiv.org/abs/2004.13538

22. H. W. Hethcote, The mathematics of infectious diseases. SIAM review, 2000. 42(4): p. 599653. 
medRxiv preprint doi: https://doi.org/10.1101/2020.05.14.20101725; this version posted May 19, 2020. The copyright holder for this preprint

(which was not certified by peer review) is the author/funder, who has granted medRxiv a license to display the preprint in perpetuity.

It is made available under a CC-BY-NC-ND 4.0 International license .

23. D. Guerrero, Spread of Covid-19: a Study Case of Honduras, Forecasting with Logistic Model and SIR Model, https://www.upnfm.edu.hn/phocadownload/Covid_19_Danny_Guerrero_Elsarticle.pdf

24. D. Smith and L. Moore, The SIR Model for Spread of Disease: The Differential Equation Model (2004).https://www.maa.org/press/periodicals/loci/joma/the-sir-model-for-spread-ofdisease-the-differential-equation-model

25. M. Batista, Estimation of the final size of the COVID-19 epidemic. medRxiv 2020: https://doi.org/10.1101/2020.02.16.20023606

26. M. Batista (2020). fitVirusCOVID19

(https://www.mathworks.com/matlabcentral/fileexchange/74658-fitviruscovid19), MATLAB

Central File Exchange. Retrieved May 12, 2020.

27. G. Pandey et. al., SEIR and Regression Model based COVID-19 outbreak predictions in India, https://arxiv.org/ftp/arxiv/papers/2004/2004.00958.pdf

28. https://www.hindustantimes.com/india-news/if-there-are-more-cases-punjab-seeks-centre-s-help-oncovid-19-as-90-000-nris-return/story-MDuL8rhvZaFIICyMUNwhVP.html

29. A. Maji, M.B. Sushma and T. Choudhari, Implication of Inter-State Movement of Migrant Workers during COVID 19 Lockdown using Modified SEIR Model, https://arxiv.org/abs/2005.04424

30. https://www.covid19india.org/ 